\title{
Research on the Development Dynamic Mechanism and Strategy of Electronic Commerce of Agricultural Products in China
}

\author{
Chunhua Hu \\ School of Management of Wuhan Donghu University, Hubei Province, China \\ 600690@163.com
}

\begin{abstract}
Keywords: Electronic commerce of agricultural products; Electronic commerce system; Dynamic mechanism; Agricultural products; Dynamic mechanism.
\end{abstract}

\begin{abstract}
As a large agricultural country, agricultural products at farmers markets and supermarkets to buy consumption concept is deeply ingrained, marketing has many defects, such as sales supply chain is too complex, farmers have no pricing power, income has always been difficult to improve, quality good buckwheat irregular; as an important means to promote the process of agricultural modernization, the significance of developing e-commerce of agricultural products far-reaching. The main body of the agricultural product electronic commerce system mainly includes the agricultural industry cooperation organization, the peasant household or the rural economic person. The driving force of the development of electronic commerce of agricultural products lies in the interaction mechanism of the factors of economic benefit, government support, social demand and technological progress. At present, we should from increased government guidance and assistance, strengthen market discipline, regulation, and enhancing farmers or agribusiness subject awareness, to promote the agricultural product electronic commerce in the circulation pattern of agricultural products to upgrade.
\end{abstract}

\section{Introduction}

Under traditional agricultural conditions, agricultural producers to market information the lack of large data unobstructed channels, has a certain lag arrangements for the production, the price of understanding, is often based on a year of market conditions and their own experience to determine this year's production arrangement, causes the product from the market caused unsalable, melon cheap is hurt farming phenomenon [1].

Relying on modern information technology and the Internet market of agricultural products, electronic commerce, has greatly improved the information is not perfect, the plight of the network, especially the Internet, can make the agricultural policy, market prices and other information timely and effectively released [2], the interaction of the online trading of agricultural products become a reality, the opening of the electricity supplier of agricultural products have broad market space [3]. As long as you know how to network online, farmer or agribusiness can arrange the production operation according to the immediate market, agricultural production more organized, and closer to the goal of agricultural industrialization.

New rural construction is the important way to solve the issues concerning agriculture, countryside and farmers, and agricultural modernization is to accelerate the new rural construction of important foundation, as an important means to promote the modernization of agriculture and the significance of developing e-commerce of agricultural products deep[4]. Agricultural e-commerce is a system, system of all relevant factors between mutual connection, interaction, thus forming power to drive the progress of system development, operation mechanism of the system, and according to promote the development and consummation of the motivation factors to determine the application strategy is necessary. 


\section{Interpretation of Electronic Commerce of Agricultural Products}

Electronic commerce of agricultural product rise has forty or fifty years of time, from the initial use of telephone contact products and transaction parties together to today's Internet into the fresh perishable products online transactions, e-commerce development really. The definition of e-commerce of agricultural products is to network media, using modern information technology to collect and instant updates and releases the information of production, supply and marketing of agricultural products, relying on the logistics system, agricultural products from the branches, the field, pond to the tongue of the whole process, involving, including government, agriculture related individual businesses, logistics distribution center and regulatory bodies, such as different entities and participants [5].

Throughout the world of mature electronic commerce system, allowing farmers to benefit from the trade of agricultural products is inseparable from the government's assistance, through price protection, financial support, policy formulation, in a certain extent, reduce market risk; of course of farmer awareness of the electronic commerce form is essential; with the realization of universal access to the Internet and electronic commerce system can improve the development of; agricultural product electronic commerce system to guarantee the order of the market of agricultural products, household income at the same time, for the agricultural production and management decision-making provides the basis, is becoming the main platform for the trade of agricultural products [6].

\section{Dynamic Mechanism}

Economic Benefit. The main body of the electronic commerce system of agricultural products mainly include the industrial cooperation in agriculture, farmers, rural economy, or e-commerce service providers, in order to achieve profit maximization, the subject will be selected out leave those with low cost and high profit prospects for development projects, as the e-commerce of agricultural products is to be carried out economic base. And agricultural product electronic commerce economic benefits are varied, from the limitation of benefit divided up, overall revenue is effective in the long term, but to farmers or brokers may only be in the short term profit project; from the point of view of the scope of income, including those who only beneficial to a regional project benefits, and to implement those up project is good for society as a whole. Agricultural products marketing channels mainly to foreign traders to purchase the main, sales channels are narrow, the supply and marketing channels are not smooth, the use of agricultural products e-commerce platform is not sufficient [7].

In the project of trade-offs and economic interests in the opposite side, cannot make a profit at the same time by a factor of two is bound to have a conflict of interest, and the conflict of interests coordination process produced power system development. At this time, the main body will hope that the government through policy incentives or regulation, in order to obtain vital interests, this is the fundamental driving force for the development of the system [8].

Government Support. In the development of agricultural e-commerce government to support and promote the role of the obvious, in the policy of increasing investment in information technology, create a social atmosphere for the development of electronic commerce, promote the construction of electronic commerce platform, training and selection of talent, are other social member irreplaceable role and status [9].

Government as the development of e-commerce of agricultural products to escort people, active support is bounded, not too much intervention agricultural enterprises or the choice of farmers, to clear the main body status, otherwise the negative effects [10].

Government in agricultural and rural development of electronic commerce in the process of positioning and the starting point needs to be clear, the reference of Zhejiang Chun'an County Magistrate Guo Dongxiao insights: "electronic commerce is a kind of tool, the government should learn the rational use of tools, the area of e-commerce development to avoid the function department of anxiety. The development of regional e-commerce is not a prison, the need in the right time, the right time to give the most reasonable guidelines and resources for the most reasonable." 
Social Demand. With the popularity of the concept of environmental protection, the rise of the green food, whether it is the bulk purchase of individual members of society or social organizations, are required to produce green, organic and pollution-free, which requires not only the production process in line with environmental standards, trading and distribution process to achieve high standards, especially the rapid development of China's 2012 fresh business, society increasingly high demand on the trading environment, which gives the government from production to the power of transaction process, strict supervision, so as to promote the improvement and development of the e-commerce of agricultural products.

Although the individual or society is government needs to promote the development of the electronic commerce system, but also requires a higher level of economic development, the national quality better, the demand pull mechanism makes sense, because of the different economic conditions and quality of the population will have different business needs, the pull effect of electronic commerce will have obvious difference. Currently have been living network, optimization of SF, Tuo Tuo industrial society, Putian net line fresh business enterprise mainly for Beijing, Shanghai, Tianjin, three regional users to provide services, because other regions, especially in three line city user awareness, consumption habits, cold chain distribution elements of the market is not mature.

Technical Progress. Science and technology is the first productive force theory has long been numerous economic cases to prove, to realize the construction of new countryside, agricultural output value added value increased and the agricultural products of modern circulation mode transition, but also inseparable from the introduction of advanced technology. Through the improvement of the original technology and integrated, or is the application of some new technologies, changing modes of production and circulation of agricultural products, agricultural production and operation can really reduce the waste of resources, yield at the same time achieve income, efficiency and to achieve value-added. In recent years, the development and application of agricultural products traceability system technology to accelerate the pace of agricultural electricity suppliers.

\section{Development Strategy}

Government is the Main Force. The electronic commerce market of agricultural products has become an important trading platform, and the government should be the leader of the system.

From the central level, in January 2014, the central first document was first proposed to strengthen the construction of agricultural e-commerce platform, laid the foundation for the development of rural electricity suppliers. It shows that the government continues to put the rural e-commerce in a strategic priority, the rural e-commerce in the rural areas of the core location of information policy oriented display electricity suppliers to the countryside is the trend. From the perspective of local government, improve the ability of government public service for the network operators in rural areas, focus on solving the outstanding problems faced in the development, such as land issues, funding issues, personnel issues such as help farmers network operators to enhance their competitiveness; encourage to Taobao Village Representative bottom-up rural e-commerce mode, encourage promote advanced models, guide farmers to network operators go set reduction, brand, ecological development path, to avoid vicious competition. Adhere to the dominant position of the farmers in rural electronic commerce, the government has taken adroitly guide action according to circumstances, and promising treatment strategy, non-intervention is not strong, good service, do a good job of supporting;

The continuity in the development of e-commerce of agricultural products, we should perfect the legislation, the legal basis for punishment of the offence; illegal crime on network increase investigation efforts to hunt, and recommended that the law enforcement departments in accordance with the regulations, to violates the trading rules, the destruction of illegal business transaction security severely punished, eliminate market to ensure transaction security of electronic commerce system; can also with the relevant parties to coordinate eliminate e-commerce market does not violate the regulations of trade barriers, to ensure that the transaction; or businesses on the honesty and credit reward praising, guarantee e-commerce market, the healthy and orderly development. 
In seeing it simplify the agricultural products trade at the same time, but also to realize that this modern agricultural products circulation in the future will become the mainstream, and give enough attention.

Electronic commerce transaction system will require the seller to provide product standards, specifications and packaging detailed information, but generally speaking, agricultural products both appearance or quality are difficult to industrial products like that kind of neat and tidy, ease of classification, together with China is not the introduction of a uniform standard of agricultural products, which requires the government to build on agricultural products quality inspection and evaluation system, suitable for the demands of the market for product specification criteria, to ensure that electronic commerce system to play a real role.

Talent is the power of the country, should encourage and support educational institutions at all levels to open agricultural e-commerce specialty and the curriculum, training in agricultural e-commerce multi-level talent; vigorously promote e-commerce official research work, play an important role in the link of e-commerce talents; encourage the development of agricultural products e-commerce services the existing e-commerce personnel to provide employment, to provide more intelligence support of the majority of farmers and agriculture related e-commerce enterprises; multi form and multi-level publicity and education in the society, including the business class, class, class, enhance the professional elite class, salon, forums and a series of informal training work.

Farmers' Participation Is the Key. Agricultural product electronic commerce farmers or agricultural enterprise is the main body, facing the new products trading, doubt and exclusion are normal, in the promotion before, can choose those areas with better conditions to carry out the pilot, received the effect after, and then gradually extended, cannot be impatient. In remote or rural poor economic foundation, organization of the network know the zero based farmers training help farmers to understand the network, understand the operation process of the transaction, and how to protect their information security, promote the expansion of the application of e-commerce system. In the process of standardization of agricultural products, be sure to encourage farmers to actively speak, more suggestions, and the final form of the standard of farmers explain clearly, let farmers know division of their products, can greatly facilitate transactions.

The Role of E-Commerce Platform Is Indispensable. E-commerce platform also known as the third-party e-commerce businesses, refers to an independent on the product or service providers and consumers, through the network service platform, according to the particular transaction and service standards, for buyers and sellers to provide services, service content can include but are not limited to "supply and demand information dissemination and search, the establishment of the transaction, payment, logistics,. In our country, this kind of enterprise is very important in the development of electronic commerce.

But in the third party e-commerce mode develops rash and too much in haste. The reason is because the platform is set up on the basis of freedom, openness, and information release in a timely manner, fully reflect the market aggregation effect. The platform will demand farmers and agriculture related enterprises meet many of our most incisive experience, farmers and farmers have tasted the sweetness.

E-Commerce Service Providers Are Important Support Factors. E-commerce service provider refers to the business of electronic business individuals and businesses to provide a variety of business services. In the development of e-commerce of agricultural products, agriculture related individuals and businesses for congenital physical area, education, production and other reasons, its own e-commerce gene and way of thinking is limited, need more at all levels of the various types of agricultural e-commerce service providers. They are the third party e-commerce platform and an important bridge between farmers, greatly promoting the rural e-commerce to the countryside speed. Business is mainly concentrated in the release of e-commerce, vision, promotion, operations, data analysis, such as the whole chain, a new industry came into being. The emergence of express logistics, marketing, training, operations and other service providers, not only effectively improve the work efficiency of the farmer network operators, operating ability, also let the agriculture electricity 
supplier industry chain more complete, and enhance the competitiveness of farmers in the network of collective. In today's national model of the transformation of the typical Taobao village on the road, the third party e-commerce service providers to become the key elements of its development level.

Rural Electricity Suppliers Public Service Center Is Imminent. In the development of e-commerce of agricultural products, the government, farmers, service providers, platform four main body part of the net demand intertwined, which requires a strong platform support, starting from the various policies, technology, market and so on, for the government, farmers, farmers or the network platform, the different needs of agricultural enterprises and role, the key factor to restrict regional positioning and the development of electronic commerce, so you can consider the establishment of regional electronic public service center, the center can be a very good relations, coordinate resources, according to the actual demand of e-commerce of agricultural products to the local conditions and the time of carrying promote resources and rational construction.

\section{Summary}

The construction of the new countryside requires us to change the traditional farming methods, international market competition requires that we change to the relative advantage of agricultural products to the absolute advantage, domestic cultivated area is under construction of modernization and urbanization, the extrusion; green consumption consciousness deeply, for agricultural production goods production and circulation are put forward quality requirements, in today's agriculture from production to circulation are in the era of profound changes in, the perfection of the system of e-commerce of agricultural products is clockwise and inevitable. In the context of today's modern information technology changes with each new day, I believe in the government's policy support, funding tilt, and regulations of the security conditions farmers use the consciousness of modern mode of production and circulation will be more and more strong, coupled with the continuous emergence of agricultural e-commerce platform, e-commerce service providers and agricultural products e-commerce talent, e-commerce system will be more and more perfect. In the process of agricultural modernization play more and more important role.

\section{References}

[1] Allan Afuah, Internet Business Models and Strategies, Text and Case, Tsinghua University Press and McGraw-Hill Press, 2002.

[2] Alan, J. Rowe and Sue Anne. Intelligent Information Systems: Meeting the Challenge of the 17. Martin James. Gybercorp-The New Business Revolution. AMACOM, New York, 1996.

[3] Hartman, John Sifonis, John Kador: Net Ready: Strategies for Success in the E-economy. 1999.

[4] Zott, C, Value Creation in eBusiness, Strategic Management Journal, Vol. 22(2001), pp. 493-520.

[5] G1enn, P. Jenkins, Information Technology and Innovation in Admin illustration. Kluwer Law International, 1996.

[6] Krishna, K., Auctions with Endogenous Valuations: the Persistence of Monopoly Revisited, The American Economic Review, Vol. 83(1993) No. 1, pp: 147-160.

[7] McAfee. R. P and J. McMillan, Electronic Markets,Addision-Weslsy,1997

[8] Paul Gray, Decision Support and Executive Information Systems, Prentice Hall,1994

[9] Prem Bhatnagar, Strategic IT Planning For India's Soybean Sector, CISCE 2002.

[10] Robert J. Mockler, Knowledge Gassed Systems for Management Decisions Prentice Hall.1989. 